\title{
Venous Hypoxia: A Poorly Studied Etiological Factor of Varicose Veins
}

\author{
C.S. Lim ${ }^{\text {a, b }}$ M.S. Gohel ${ }^{a} \quad$ A.C. Shepherd ${ }^{\text {a }}$ E. Paleolog ${ }^{\text {b A.H. Davies }}{ }^{a}$ \\ a Imperial Vascular Unit, Department of Surgery and Cancer, Faculty of Medicine, Charing Cross Hospital, \\ Imperial College London, and ${ }^{b}$ Cytokine Biology of Vessels Group, Kennedy Institute of Rheumatology and \\ Department of Surgery and Cancer, Faculty of Medicine, Imperial College London, London, UK
}

\section{Key Words}

Hypoxia $\cdot$ Varicose veins $\cdot$ Vein and oxygen

\begin{abstract}
Venous hypoxia has long been postulated as a potential cause of varicosity formation. This article aimed to review the development of this hypothesis, including evidence supporting and controversies surrounding it. Vein wall oxygenation is achieved by oxygen diffusing from luminal blood and vasa vasorum. The whole media of varicosities is oxygenated by vasa vasorum as compared to only the outer two-thirds of media of normal veins. There was no evidence that differences exist between oxygen content of blood from varicose and non-varicose veins, although the former demonstrated larger fluctuations with postural changes. Studies using cell culture and ex vivo explants demonstrated that hypoxia activated leucocytes and endothelium which released mediators regulating vein wall remodelling similar to those observed in varicosities. Venoactive drugs may improve venous oxygenation, and inhibit hypoxia activation of leucocytes and endothelium. The evidence for hypoxia as a causative factor in varicosities remains inconclusive, mainly due to heterogeneity and poor design of published in vivo studies. However, molecular studies have shown that hypox-
\end{abstract}

ia was able to cause inflammatory changes and vein wall remodelling similar to those observed in varicosities. Further studies are needed to improve our understanding of the role of hypoxia and help identify potential therapeutic targets.

Copyright $\odot 2010$ S. Karger AG, Basel

\section{Introduction}

Varicose veins are excessively dilated, elongated and tortuous veins, and affect up to a third of the adult population in Europe $[1,2]$. The cost of treating varicose veins and associated complications has been estimated at 1-3\% of the total annual health care budget in European countries [3]. Despite the unquestionable clinical significance of the condition, the pathogenesis of varicose veins remains unclear. There is increasing evidence that alteration of the vein wall is the primary abnormality in varicose veins $[4,5]$. Numerous changes in cellular and extracellular matrix components of the vein wall have been identified, including intimal hyperplasia, smooth muscle cell dysfunction, changes to the collagen and elastin content and imbalances of matrix metalloproteinases and their tissue inhibitors [4-7]. These changes are thought to cause an overall weakening and relaxation of vein wall

\section{KARGER}

Fax +41613061234 E-Mail karger@karger.ch www.karger.com

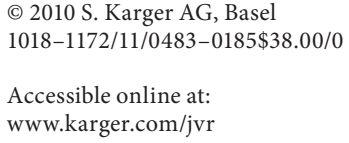

Prof. Alun H. Davies

Imperial Vascular Unit, 4 East, Charing Cross Hospital

Fulham Palace Road

London W6 8RF (UK)

Tel. +44 203311 7320,Fax +44203311 7362, E-Mail a.h.davies@imperial.ac.uk 
leading to venous dilatation, valve incompetence and reflux.

Vein wall hypoxia has been suggested as a contributing factor for varicose vein formation $[5,6,8,9]$. For several decades, many in vivo and in vitro studies have assessed the relationship between hypoxia and varicose vein formation. However, opinions remain divided on the evidence evaluating hypoxia as a possible factor contributing to varicose vein formation. The aim of this article was to revisit and review the published evidence for the controversial hypothesis of vein wall hypoxia contributing to the formation of varicose veins.

\section{Methods}

PubMed, Embase and Ovid Medline databases were searched using the terms 'varicose veins and blood oxygen', 'varicose veins and vasa vasorum' and 'varicose veins and hypoxia'. No date limitation was used during the search. All available abstracts were reviewed. Of these, articles that discussed the relationships between oxygenation and varicose vein formation were evaluated. Articles that were not related to chronic venous disease were excluded. This review focused on studies assessing the relationship between oxygen tension and varicose vein formation in patients of clinical stages C2 to C6 of Clinical Etiology Anatomical Pathophysiology classification.

\section{Blood Supply to the Vein Wall}

Vein wall oxygenation is achieved by diffusion of oxygen from blood in the lumen and vasa vasorum. The lumen of the superficial venous system of the lower limbs contains deoxygenated blood from skin and subcutaneous tissue of the legs. Meanwhile, vasa vasorum of the saphenous veins and tributaries originate from feeding arteries in the surrounding adipose tissue and penetrate the fascia of the veins before opening into the media and adventitia [10]. It has been reported that the main sources of blood in the vasa vasorum for the great saphenous vein (GSV) were the external pudendal artery and descending artery of the knee, while for the small saphenous vein the main sources of blood were the small saphenous artery which is a branch of the popliteal artery [11].

In a study to assess the oxygenation of the vein wall, Taccoen et al. [9] used a microdriven stepwise progression needle probe attached to a computerized polarographic system to measure the in vivo oxygen tension across the saphenous vein wall of patients undergoing surgery. The authors found that the oxygen tension of the saphenous vein wall decreased from the adventitia to the union of the middle and inner third of the media followed by a marked increase in oxygen tension in the intima and lumen. This suggested that the oxygenation of the inner one third of the vein wall was provided by luminal blood and the outer two thirds by vasa vasorum. This was supported by several detailed histological and anatomical studies of vasa vasorum including those in saphenous veins. These studies found that in normal veins, vasa vasorum only opened into the adventitia and outer two thirds of the media but never into the inner one third and intima $[10,12]$.

The relative oxygenation and nourishment of the vascular wall contributed by the luminal blood, and vasa vasorum may vary depending on several factors including the type and size of the vessel and luminal oxygen tension $\left(\mathrm{PO}_{2}\right)[10,13]$. Despite having a thicker wall, the overall relative contribution of oxygenation from blood in the vasa vasorum is less in arteries than in veins [13]. It has been postulated that low oxygen content of the luminal blood in the veins is compensated by increased formation of vasa vasorum [13]. Conversely, veins with relatively thinner walls were found to have lower blood flow in the vasa vasorum in comparison to veins with thicker media $[12,13]$. It has also been found that vasa vasorum dilate leading to increased blood flow when veins were subjected to acute hypoxia [13].

Pathological changes in the vein wall including intimal hyperplasia and degenerative changes in the innermost layer such as in varicosities and phlebosclerosis have also been found to be associated with alterations to the distribution and density of vasa vasorum. In areas of intimal hyperplasia, vasa vasorum were found to penetrate the whole media as compared to only the outer two thirds of the media in normal segments of veins [12]. Similar observations were reported by Bigel and Taccoen [14] in varicose veins where the vasa vasorum were increased close to the intimal layer but not in non-varicose veins. In a study of 22 patients, Kachlik et al. [15] found increased numbers of vasa vasorum in varicose veins, especially recurrent varicose veins and those with thrombophlebitis compared to non-varicose veins. Interestingly, tortuosity and irregular dilatations of adventitial veins were also observed in varicose veins. It has been suggested that degenerative changes and intimal hyperplasia in the innermost layer of the vein wall cause intraluminal and/or intramural hypoxia. This may lead to an increase in vasa vasorum via neovascularization to ensure adequate oxygenation of the entire media [12]. 


\section{Potential Mechanisms of Vein Wall Hypoxia in Varicose Veins}

Inadequate oxygen supply from luminal blood or vasa vasorum or both could potentially cause vein wall hypoxia. Two mechanisms, both related to blood stasis and venous hypertension, have been proposed to cause hypoxia to the varicose vein wall:

(1) Endoluminal hypoxia: stagnation of venous blood flow results in reduced oxygen replenishment in comparison to normal venous flow. Endothelial and inner layers of the vein wall are first affected in endoluminal hypoxia [16-18].

(2) Medial hypoxia: distension of the vein by hydrostatic pressure secondary to blood stasis causes compression of vasa vasorum. Therefore, the media and outer layers of the vein wall are first affected $[17,18]$.

\section{Measuring Luminal Blood Oxygenation in Varicose Veins}

For many decades, researchers have attempted to assess the oxygen content of venous blood carried in varicose and non-varicose veins. However, findings from these studies have been inconsistent as some studies demonstrated a lower oxygen content in blood from varicose compared to non-varicose veins [19-21], whereas others showed no significant differences [22-26]. Paradoxically, some studies even reported higher oxygen content in blood of varicose than non-varicose veins [22, 23, 27-29]. Numerous factors may have contributed to these variations. Clearly, huge inconsistencies in study design and sampling variations existed between studies as contralateral superficial veins, deep veins, femoral veins and antecubital veins had all been used as controls, and the posture of patients during sampling was not consistent [20, 26, 27]. Moreover, in some studies, non-varicose and varicose veins of the same patients were compared while in others, patients without varicosities were recruited as controls [20,30].

Studies comparing the venous blood oxygen content between varicose and superficial leg veins of patients without varicose vein disease are summarized in tables 1 and 2. On the basis of current evidence, it is not possible to conclude that the blood in the lumen of varicose veins contains less oxygen than blood in non-varicose veins. Interestingly, in non-dependent (lying) positions, the oxygen content of blood from varicose veins appeared to be similar or even higher than that of non-varicose veins. In the dependent positions, the oxygen content of blood from both varicose and non-varicose veins decreased, but the reduction may be greater in blood from varicose veins $[22,23]$.

\section{Measuring Oxygenation in Varicose Vein Wall}

Our literature search only found one study that measured and compared vein wall oxygen tension between varicose and non-varicose veins in vivo. In this study, Taccoen et al. [9] compared the vein wall oxygen tension of 31 varicose saphenous veins (from 21 patients during venous surgery) with 7 non-varicose saphenous veins in patients undergoing femoro-popliteal bypass surgery. The authors reported that the average minimum oxygen tensions were significantly lower in the media of varicose compared to non-varicose veins (7.9 vs. $13.4 \mathrm{~mm} \mathrm{Hg}$; $<$ $0.05)$. Although study samples were small, this was the only study that measured the vein wall oxygen tension directly, and it reported that the wall of varicose veins may be hypoxic compared to non-varicose veins.

\section{Molecular Studies}

\section{Expression Studies}

Venous stasis may cause oxidative stress by initiating a series of haemodynamic, metabolic, and nutritional changes including tissue hypoxia [31-33]. In a study of 45 patients with varicosities, downregulation of cytochrome-oxidase $\mathrm{C}$ and increased pyruvate expression in varicose compared to non-varicose portions of the veins suggested a reduction in oxidative phosphorylation in varicose veins [34]. Varicose vein wall has also been shown to consume less oxygen and glucose [35], and demonstrates elevated oxidative stress, including increased thiobarbituric acid reactive substances, myeloperoxidase and xanthine oxidase [36], compared to non-varicose veins.

Elevated oxidative stress has been associated with vein wall injury and chronic venous insufficiency (CVI) [31$33,37]$. Moreover, leucocytes in the blood of varicose veins demonstrated increased oxidative stress compared with arm veins in patients with CVI $[38,39]$. Leucocyte trapping and oxygen free radical (superoxide dismutase and superoxide anions) retention in lower limbs were also significantly increased in patients with varicose veins compared to those without in gravity-dependent positions [40]. Interestingly, the level of oxidative stress mea- 
Table 1. Summary of the designs and findings of studies that measure and compare oxygenation of blood in varicosities of patients and leg veins of controls with no varicose vein disease

\begin{tabular}{|c|c|c|c|c|c|}
\hline Study & Patients & Controls & $\begin{array}{l}\text { Other veins } \\
\text { studied }\end{array}$ & Positions & Results \\
\hline $\begin{array}{l}\text { Holling et al. } \\
{[23], 1938}\end{array}$ & $\begin{array}{l}\text { Varicose veins of } \\
13 \text { patients } \\
\text { ( } 7 \text { without and } \\
6 \text { with ulcers) }\end{array}$ & $\begin{array}{l}\text { Similarly located veins of } \\
4 \text { patients with no varicose } \\
\text { veins. }\end{array}$ & Nil & $\begin{array}{l}\text { 'From bed and } \\
\text { seated for } 2 \mathrm{~h} \\
\text { with his foot in a } \\
\text { dependent position' }\end{array}$ & $\begin{array}{l}\text { No significant difference between } \\
\text { oxygenation of blood of varicose and } \\
\text { non-varicose veins. }\end{array}$ \\
\hline $\begin{array}{l}\text { Schraibman } \\
{[25], 1966}\end{array}$ & $\begin{array}{l}\text { Varicose veins of } \\
62 \text { patients }\end{array}$ & $\begin{array}{l}\text { Leg veins of } 14 \text { patients } \\
\text { with no varicose veins }\end{array}$ & $\begin{array}{l}\text { Femoral arteries } \\
\text { and femoral } \\
\text { veins }\end{array}$ & $\begin{array}{l}2 \text { and } 10 \text { min of } \\
\text { standing from a } \\
\text { recumbent position }\end{array}$ & $\begin{array}{l}\text { No significant difference between the } \\
\text { oxygen saturation of blood from varicose } \\
\text { and non varicose veins. }\end{array}$ \\
\hline $\begin{array}{l}\text { McEwan and } \\
\text { McArdle } \\
{[19], 1971}\end{array}$ & $\begin{array}{l}\text { Varicose veins of } \\
14 \text { patients with } \\
\text { impaired distal } \\
\text { skin nutrition }\end{array}$ & $\begin{array}{l}\text { Leg veins of } 6 \text { patients } \\
\text { without varicose veins }\end{array}$ & Nil & $\begin{array}{l}\text { Sitting with studied } \\
\text { legs in dependent } \\
\text { position for } 10-15 \\
\text { min }\end{array}$ & $\begin{array}{l}\mathrm{PvO}_{2} \text {, oxygen saturation and calculated } \\
\text { venous oxygen content were significantly } \\
\text { lower in blood from varicose than non- } \\
\text { varicose veins. Oxygen extraction in } \\
\text { tissues was significantly higher in } \\
\text { varicose than non-varicose veins. }\end{array}$ \\
\hline $\begin{array}{l}\text { Blumoff and } \\
\text { Johnson } \\
{[29], 1977}\end{array}$ & $\begin{array}{l}\text { Varicose veins of } \\
20 \text { patients }\end{array}$ & $\begin{array}{l}\text { Saphenous veins } \\
\text { harvested for either } \\
\text { aortico-renal or femoro- } \\
\text { popliteal bypass graft of } \\
18 \text { patients with no } \\
\text { varicose veins }\end{array}$ & $\begin{array}{l}\text { Femoral } \\
\text { arteries, femoral } \\
\text { veins and } \\
\text { proximal } \\
\text { saphenous veins }\end{array}$ & $\begin{array}{l}\text { Supine (operated } \\
\text { with endotracheal } \\
\text { anaesthesia) }\end{array}$ & $\begin{array}{l}\mathrm{PvO}_{2} \text { was significantly higher in varicose } \\
\text { than non-varicose saphenous veins. } \mathrm{PvO}_{2} \\
\text { of superficial leg veins were significantly } \\
\text { higher than that of the femoral veins in } \\
\text { patients with and without varicose veins. }\end{array}$ \\
\hline $\begin{array}{l}\text { Reikerås and } \\
\text { Sorlie } \\
{[21], 1983}\end{array}$ & $\begin{array}{l}\text { Varicose veins of } \\
22 \text { patients } \\
\text { (6 were } \\
\text { recurrences) }\end{array}$ & $\begin{array}{l}\text { Leg veins of } 9 \text { patients } \\
\text { with no varicose veins }\end{array}$ & Popliteal veins & Standing & $\begin{array}{l}\mathrm{PvO}_{2} \text { was significantly lower in varicose } \\
\text { than non-varicose saphenous veins. } \mathrm{PvO}_{2} \\
\text { was significantly lower in varicose than } \\
\text { contralateral non-varicose veins of } \\
\text { patients with varicose veins. }\end{array}$ \\
\hline $\begin{array}{l}\text { Baron and } \\
\text { Cassaro } \\
{[28], 1986}\end{array}$ & $\begin{array}{l}\text { Varicose veins of } \\
49 \text { patients }\end{array}$ & $\begin{array}{l}\text { Leg veins of } 43 \text { patients } \\
\text { with no varicose veins }\end{array}$ & $\begin{array}{l}\text { Antecubital } \\
\text { veins }\end{array}$ & Recumbent position & $\begin{array}{l}\mathrm{PvO}_{2} \text {, oxygen saturation and calculated } \\
\text { venous oxygen content were significantly } \\
\text { higher in blood from varicose than non- } \\
\text { varicose veins. }\end{array}$ \\
\hline $\begin{array}{l}\text { Scott et al. } \\
{[22], 1990}\end{array}$ & $\begin{array}{l}\text { Varicose veins of } \\
13 \text { patients }\end{array}$ & $\begin{array}{l}\text { Leg veins of } 13 \text { patients } \\
\text { without varicose veins }\end{array}$ & $\begin{array}{l}\text { Antecubital } \\
\text { veins }\end{array}$ & $\begin{array}{l}\text { Laid supine for } 20 \\
\text { min and stood for } \\
30 \text { min with arms at } \\
\text { the sides }\end{array}$ & $\begin{array}{l}\mathrm{PvO}_{2} \text { was significantly higher in varicose } \\
\text { than non-varicose veins during supine } \\
\text { position. No significant difference was } \\
\text { noted in } \mathrm{PvO}_{2} \text { between varicose and } \\
\text { non-varicose veins during standing. } \\
\mathrm{PvO}_{2} \text { was significantly higher in leg veins } \\
\text { than in arm veins in both the varicose } \\
\text { and non-varicose vein groups during } \\
\text { supine. } \mathrm{PvO}_{2} \text { in leg veins dropped } \\
\text { significantly from supine to standing in } \\
\text { both the varicose and nonvaricose vein } \\
\text { groups. }\end{array}$ \\
\hline $\begin{array}{l}\text { Wali } \\
{[26], 2002}\end{array}$ & $\begin{array}{l}\text { Varicose veins of } \\
21 \text { patients }\end{array}$ & $\begin{array}{l}\text { Leg veins of } 21 \text { controls } \\
\text { (doctors and nurses) with } \\
\text { no varicose veins }\end{array}$ & $\begin{array}{l}\text { Antecubital } \\
\text { veins }\end{array}$ & $\begin{array}{l}\text { At least } 5 \text { min of } \\
\text { standing before } \\
\text { venepuncture of leg } \\
\text { veins and sitting for } \\
\text { antecubital veins }\end{array}$ & $\begin{array}{l}\text { No significant difference in } \mathrm{PvO}_{2} \text { and } \\
\text { oxygen saturation between blood of } \\
\text { varicose and non-varicose veins during } \\
\text { standing. } \mathrm{PvO}_{2} \text { and oxygen saturation } \\
\text { were significantly higher in veins of the } \\
\text { lower than upper limbs of patients with } \\
\text { varicose veins. In controls, oxygen } \\
\text { saturation and } \mathrm{PvO}_{2} \text { also seemed to be } \\
\text { higher in veins of the lower than upper } \\
\text { limbs (only significant in the former). }\end{array}$ \\
\hline $\begin{array}{l}\text { Murphy and } \\
\text { Hands } \\
{[24], 2008}\end{array}$ & $\begin{array}{l}\text { Varicose veins of } \\
39 \text { patients } \\
(\mathrm{C} 2-\mathrm{C} 6)\end{array}$ & $\begin{array}{l}\text { Median cubital veins of } 10 \\
\text { patients underwent hernia } \\
\text { repair and } \\
\text { cholecystectomy }\end{array}$ & Nil & $\begin{array}{l}2 \text { min of lying and } 2 \\
\text { min of standing }\end{array}$ & $\begin{array}{l}\text { No significant difference of } \mathrm{PvO}_{2} \\
\text { between varicose and control veins. } \\
\text { Reduction of } \mathrm{PvO}_{2} \text { in both varicose and } \\
\text { control veins during standing compared } \\
\text { to supine (significance not reported). }\end{array}$ \\
\hline
\end{tabular}


Table 2. Mean values of the oxygen tension and saturation of blood sampled from varicosities of patients and leg veins of controls with no varicose veins in gravity-dependent and non-gravity-dependent positions

\begin{tabular}{|c|c|c|c|c|c|}
\hline Study and group & $\begin{array}{l}\text { Number of } \\
\text { subjects }\end{array}$ & $\begin{array}{l}\text { Mean } \mathrm{O}_{2} \text { tension of } \\
\text { controls in non-gravity- } \\
\text { dependent positions } \\
\mathrm{mm} \mathrm{Hg}\end{array}$ & $\begin{array}{l}\text { Mean } \mathrm{O}_{2} \text { saturation of } \\
\text { controls in non-gravity- } \\
\text { dependent positions } \\
\%\end{array}$ & $\begin{array}{l}\text { Mean } \mathrm{O}_{2} \text { tension of } \\
\text { controls in gravity- } \\
\text { dependent positions } \\
\mathrm{mm} \mathrm{Hg}\end{array}$ & $\begin{array}{l}\text { Mean } \mathrm{O}_{2} \text { saturation } \\
\text { of controls in } \\
\text { gravity-dependent } \\
\text { positions, \% }\end{array}$ \\
\hline \multicolumn{6}{|l|}{ Controls without varicose veins } \\
\hline Holling et al. [23], 1938 & 4 & 42.1 & 71.4 & 35.8 & 63.4 \\
\hline Schraibman [25], 1966 & 14 & not tested & not tested & not tested & $57.4^{1}$ \\
\hline McEwan and McArdle [19], 1971 & 6 & not tested & not tested & 35.2 & 78.3 \\
\hline Blumoff and Johnson [29], 1977 & 18 & 54.0 & not tested & not tested & not tested \\
\hline Reikerås and Sorlie [21], 1983 & 9 & not tested & not tested & 35.3 & not tested \\
\hline Baron and Cassaro [28], 1986 & 43 & 36.1 & 64.2 & not tested & not tested \\
\hline Scott et al. [22], 1990 & 13 & 34.1 & not tested & 28.1 & not tested \\
\hline Wali [26], 2002 & 21 & not tested & not tested & 31.0 & 54.8 \\
\hline Murphy and Hands [24], 2008 & 10 & not specified & not tested & not specified & not tested \\
\hline \multicolumn{6}{|l|}{ Controls without varicose veins } \\
\hline Holling et al. [23], 1938 & 13 & 39.3 & $70.2^{2}$ & $31.1^{2}$ & 54.0 \\
\hline Schraibman [25], 1966 & 62 & not tested & not tested & not tested & $55.9^{3}$ \\
\hline McEwan and McArdle [19], 1971 & 14 & not tested & not tested & 22.7 & 54.4 \\
\hline Blumoff and Johnson [29], 1977 & 20 & 69.0 & not tested & not tested & not tested \\
\hline Reikerås and Sorlie [21], 1983 & 22 & not tested & not tested & 27.0 & not tested \\
\hline Baron and Cassaro [28], 1986 & 49 & 59.3 & 87.6 & not tested & not tested \\
\hline Scott et al. [22], 1990 & 13 & 45.7 & not tested & 30.1 & not tested \\
\hline Wali [26], 2002 & 21 & not tested & not tested & 31.0 & 52.3 \\
\hline Murphy and Hands [24], 2008 & 39 & 33.8 & not tested & 29.3 & not tested \\
\hline
\end{tabular}

${ }^{1}$ Only 12 readings out of the 14 patients studied were available in the article.

${ }^{2}$ Only 12 readings out of the 13 patients studied were available in the article.

${ }^{3}$ Only 61 readings out of the 62 patients studied were available in the article.

sured in the blood obtained from foot veins of patients with incompetent GSV were significantly reduced and returned to normal levels following GSV stripping [37], suggesting that venous reflux caused elevated oxidative stress.

Jacob et al. [30] investigated the effect of blood stasis on the expression of 12 biological markers and measured the $\mathrm{PO}_{2}$ of blood sampled from varicose veins and paired brachial veins (controls) of 22 patients. Several plasma endothelial and leukocyte activation markers including intercellular adhesion molecule-1 (ICAM-1), vascular cell adhesion molecule-1, angiotensin converting enzyme, pro-matrix metalloproteinases and L-selectin were significantly elevated by postural blood stasis (limbs in the dependent position compared to lying flat) in varicose veins. Such elevations were not observed in blood sampled from brachial veins. Furthermore, upregulation of these markers in varicose veins was inversely proportional to the $\mathrm{PO}_{2}$ of the blood sampled. This study demonstrated that venous endothelium and leucocytes were ac- tivated by blood stasis. These changes were associated with reductions in $\mathrm{PO}_{2}$ in varicose veins.

\section{In vitro Studies}

The importance of the endothelium in vein wall remodeling has been increasingly recognized in recent years $[4,5,8]$. Endothelial roles include regulation of coagulation, inflammation, smooth muscle cell function, and synthesis of vasoactive substances and extracellular matrix $[41,42]$. The location of the endothelium directly in contact with luminal blood exposes this layer to endoluminal hypoxia in varicose veins.

Venous endothelial responses to hypoxia have often been studied with cell culture including human umbilical vein endothelial cell (HUVEC) culture. Venous endothelial cell culture studies have demonstrated that hypoxia altered venous metabolic regulatory pathways including reduction of adenosine triphosphate (ATP) and oxidative phosphorylation and increase in glycolysis [43, 44]. Increased intracellular calcium concentration has 
also been shown in hypoxic venous endothelial cells, leading to activation of phospholipid $\mathrm{A}_{2}$ and elevated prostaglandin synthesis $[45,46]$. Alteration of these cellular processes is thought to cause the release of inflammatory mediators [47]. Activation of venous endothelial cells by hypoxia also increases the release of $\beta$-fibroblast growth factors (bFGF) and prostaglandin $\mathrm{F}_{2} \alpha$, which are known to stimulate smooth muscle cell migration and proliferation, a feature commonly observed in varicosities $[6,46,48]$. In vitro studies using venous endothelial cell culture have demonstrated that hypoxia increased angiogenesis by upregulating the release of pro-angiogenic factors such as vascular endothelial growth factor (VEGF) and bFGF $[48,49]$.

Venous endothelial cells also responded to hypoxia by upregulating hypoxia-inducible factors (HIFs) [50-52]. HIFs are nuclear transcriptional factors that regulate the transcription of many genes involved in oxygen homeostasis [53]. The transcriptional activity of HIF in venous endothelial cells has been shown to be elevated during hypoxia. Examples of genes regulated by HIF that have been shown to be increased in hypoxic venous endothelial cells include VEGF and an endothelial isoform of nitric oxide synthase (eNOS) [50-52]. Increased prostaglandin $\mathrm{I}_{2}$ and cyclo-oxygenase- 2 expression in hypoxic venous endothelial cells has also been shown to be HIFdependent [54].

In addition to cell culture, vein organ cultures have also been used to study whole venous tissue behavior in relation to hypoxia. An early study of oxidative metabolism and glucose transport in varicose vein organ cultures suggested that the oxygen consumption of human varicose veins was relatively low and comparable to healthy veins investigated in other studies [55]. However, in the absence of a control group, it is difficult to draw firm conclusions regarding oxygen consumption between varicose and non-varicose veins from this study [55].

Leucocyte infiltration has been found to be more common in histological specimens of varicose than non-varicose veins $[5,56]$. Adhesion molecule expressions such as vascular adhesion molecule-1 (VCAM-1), ICAM-1 and von Willebrand factor, which activate leucocytes, were found to be upregulated in varicose compared to nonvaricose veins $[5,56]$. Activated leucocytes secrete high levels of superoxide anions and proteases which degrade extracellular matrix [8]. To investigate whether such a phenomenon can be caused by hypoxia, HUVECs were exposed to hypoxia and treated with non-stimulated polymorphonuclear nuclear $(\mathrm{PMN})$ cells $[41,42,57]$. This model demonstrated a clear increase in PMN cell adherence to HUVECs when the $\mathrm{PO}_{2}$ decreased below $25 \mathrm{~mm}$ $\mathrm{Hg}$ [8]. Both HUVECs and PMN cells were activated by hypoxia with upregulation of adhesion molecules including CD-18-dependent adhesion molecules and ICAM-1, superoxide anions, and leukotriene $\mathrm{B}_{4}[42,58-60]$. Similar observations were also observed in whole-vein explants exposed to hypoxia. Michiels et al. [61] described an in vitro model that assessed the effect of hypoxia on saphenous vein explants in the presence of non-stimulated PMN cells. Non-varicose segments of GSV incubated in hypoxic and normoxic environments were perfused with radiolabeled PMN cells. This study demonstrated an increased number of activated PMN cells retained in veins incubated in hypoxic compared to normoxic conditions. PMN cells in hypoxia were also found to produce more superoxide anions and leukotriene $\mathrm{B}_{4}$. Such in vitro models and varicose veins in vivo revealed similar histological appearances and behaviors, hence prompting the authors to postulate that hypoxia, as a result of blood stasis, was the trigger for endothelial cell responses that could cause alterations of the venous wall and varicose vein development [8].

\section{Hypoxia and Treatment of Varicose Veins}

Few studies have investigated potential pharmacologic agents that may protect the vein wall from hypoxia. The most commonly studied group of pharmacological agents in this context has been the venoactive drugs such as flavonoids $[19,41,55,57,62]$. Venoactive drugs are often derived from plant extracts, and their therapeutic actions include increased venous tone, reduced vein wall inflammation and decreased capillary permeability $[6,63]$.

In vitro models have been used to investigate the effects of venoactive drugs on hypoxia-induced endothelial and PMN activation $[41,57]$. In a HUVEC model, aescine was shown to inhibit hypoxia-induced activation of endothelial cells, leucocytes, and the interactions of these cells in a dose-dependent manner [41, 57]. Venoactive drugs were also shown to target complexes I and III of the mitochondrial respiratory chain or adenine nucleotide translocase, reduce oxidative stress, and increase ATP synthesis during hypoxia $[8,41,64]$. A further study used an ex vivo vein explant model and found that flavonoids significantly reduced the oxygen consumption of varicose veins [55].

One clinical study reported that patients who took hydroxyethylrutosides (Paroven ${ }^{\mathrm{TM}}$ ) $250 \mathrm{mg}$, a flavonoid, 
4 times a day for 4 weeks showed significant improvements in the $\mathrm{PO}_{2}$ and saturation of blood sampled from varicose veins compared to initial levels [19]. These improvements in varicose vein oxygenation were also associated with symptomatic relief in this patient group [19]. However, the findings of this study should be interpreted with caution as patients were not randomized, neither patients nor clinicians were blinded, and the timing of venepuncture was not matched between the study groups. It was also unclear whether the patients in the study received any other treatment such as compression which might have positive effects on the oxygenation of the luminal blood. Some randomized controlled trials have also reported that venoactive drugs such as flavonoids and horse-chestnut extracts improved symptoms of CVI $[63,65-67]$. These drugs are likely to increase venous tone and decrease vein wall inflammation and capillary permeability $[6,63]$. Flavonoids such as micronized purified flavonoid fraction, containing $90 \%$ diosmin and $10 \%$ hesperidin, may also protect the vein wall from hypoxia and inhibit the expression of adhesion molecules on endothelium and leucocyte $[6,17,67$, 68].

\section{Discussion}

Hypoxia has often been proposed as a factor contributing to or even causing varicose vein formation [61]. Although varicose vein wall hypoxia has been investigated for several decades, the evidence supporting or refuting this theory remains debatable. Measuring luminal blood oxygen content in varicose and non-varicose veins might appear to be an obvious way to assess if varicose veins are hypoxic, and this approach has been used repeatedly. However, results from these studies have been inconsistent and inconclusive. Such inconsistency was likely to be due to the heterogeneity of controls used, timing and site of venepuncture, subject posture and method of oxygen measurement. Although the luminal blood oxygen content in varicose veins may not be lower than that in non-varicose veins, the evidence suggests that postural changes from gravity-independent to dependent position induce luminal blood hypoxia in both varicose and non-varicose veins, possibly through blood stasis. Furthermore, the drop in luminal blood oxygen content during such postural changes seems to be greater in varicose veins. One possible explanation may be that the varicose vein wall suffers more stress due to a drop in endoluminal oxygen ten- sion when moving to an upright position compared to non-varicose veins [30].

Unfortunately, only one study has assessed and compared varicose and non-varicose vein wall oxygen content directly and demonstrated reduced $\mathrm{PO}_{2}$ in varicose veins [9]. Such observations need to be confirmed by further studies before we can conclude that varicose veins are hypoxic. Studies on the anatomical distribution and physiology of vasa vasorum demonstrated variations between varicose and non-varicose veins [10, 12]. It is likely that the increased blood supply from vasa vasorum in varicose veins is associated with endoluminal hypoxic stress, a major cause of neovascularization. Increased angiogenesis in response to hypoxia is part of an adaptive response aimed at achieving increased delivery of oxygen and nutrients to tissues. In vitro studies have clearly demonstrated that hypoxia upregulates the formation of new vessels through activation of the HIF pathway, leading to the release of pro-angiogenic factors such as VEGF and bFGF $[48,49]$.

In vitro studies have demonstrated that venous tissues responded to the hypoxic environment by upregulation of inflammatory processes, similar to varicose veins in vivo [69]. Increases in adhesion molecules and leucocyte activation and adherence to endothelium have also been shown experimentally to be associated with postural blood stasis, more so in varicose compared to non-varicose veins [30], with similar changes seen in cell and organ cultures subjected to hypoxic conditions $[8,16,42$, 70]. These findings support the hypothesis that hypoxia secondary to blood stasis may contribute to the inflammatory processes observed in varicose veins. Figure 1 summarizes the potential mechanisms that induce hypoxia and lead to varicose vein formation and possible pharmacological targets.

It should be recognized that hypoxia may be a contributing factor to varicose vein formation, but other possibly related factors, including mechanical stretch and low shear stress, may also cause similar inflammatory processes [71-73]. Venous hypertension stretches the vein wall which could then cause venous hypoxia secondary to increased oxygen demand and compression of vasa vasorum. On the other hand, venous hypoxia also causes vein relaxation, leading to blood stasis, venous hypertension, increased vein wall tension and low shear stress. These stresses are also known to cause injury to the vein wall, leading to inflammation, which is a known feature of varicose veins [6]. Therefore, studying the role of an individual factor is reductionist. It is likely that a combination of several factors contributes to the pathogenesis 


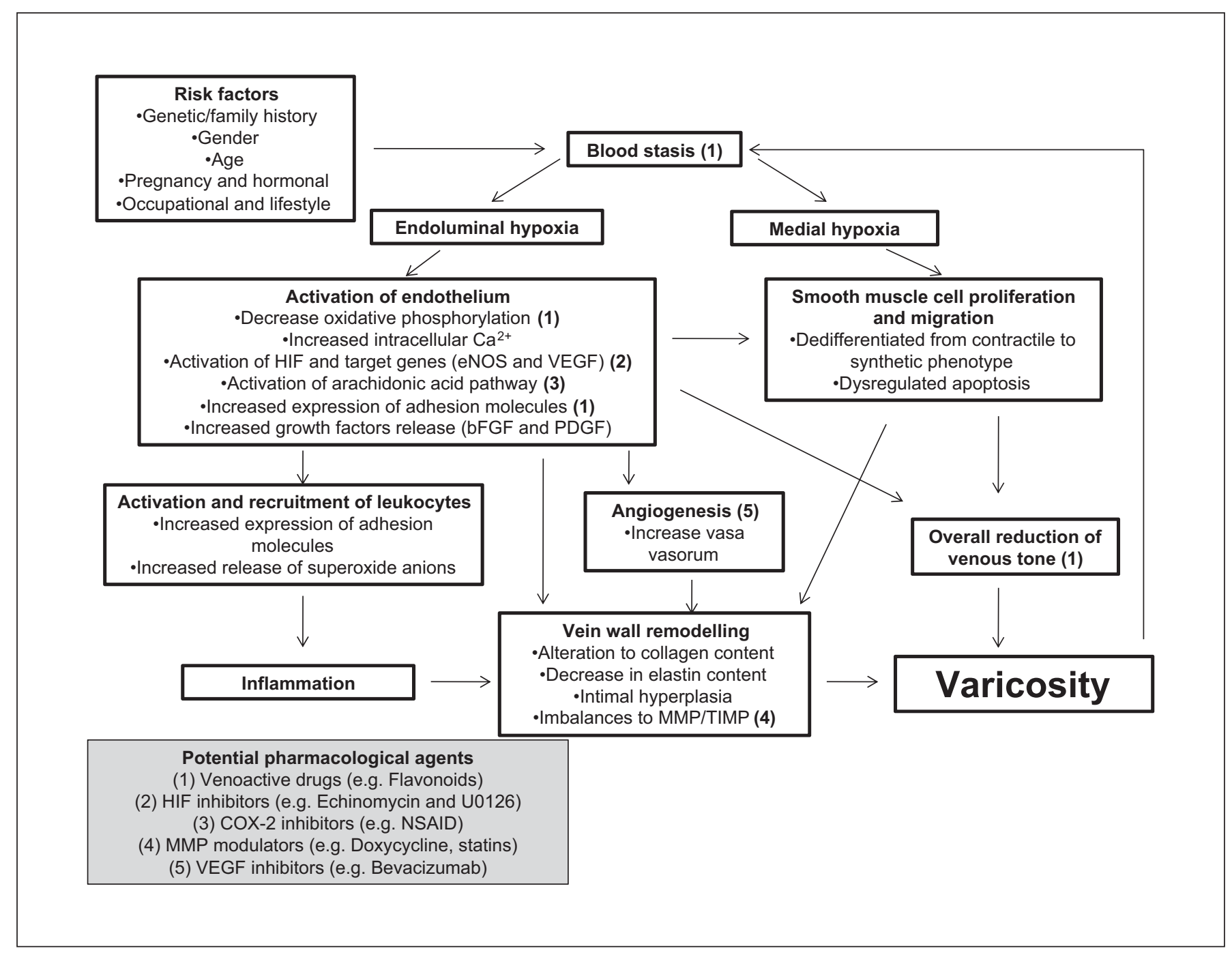

Fig. 1. Schematic diagram of potential mechanisms that induce hypoxia and lead to varicose vein formation, and possible pharmacological targets. Potential targets are numbered with Arabic numerals with their corresponding group of drug pharmacological agents shown in the grey box. eNOS = Endothelial nitric oxide synthase; VEGF = vascular endothelial growth factor; bFGF = basic fibroblast growth factor; PDGF = platelet-derived growth factor; $\mathrm{MMP}=$ matrix metalloproteinase; TIMP = tissue inhibitor of matrix metalloproteinase; COX-2 = cyclo-oxygenase- 2 ; NSAID = non-steroidal anti-inflammatory drug.

of varicose veins. The heterogeneity of the disease including the various associated risk factors and huge variation of severity of the skin changes may also contribute to the complex pathogenesis.

We recognize that our review is limited by the heterogeneity of studies published between 1938 and 2009 . Techniques and patients assessed varied hugely between reports. Patients with skin changes and ulceration may be more likely to show inflammatory activity and reduced venous oxygenation compared to patients without these complications. Despite the uncertainty, there are suggestions that tissue hypoxia may contribute to the remodelling seen in the varicose vein wall, and further investigation seems worthwhile. Furthermore, improving venous oxygenation, for example using flavonoids, may lead to symptomatic relief in CVI [17, 19, 66, 67]. Interestingly, these drugs have been shown to improve venous oxygenation most likely by elevating venous tone, increasing ATP production, reducing vein wall inflammation and decreasing capillary permeability $[35,64,66]$. Moreover, 
improving our understanding of the role of hypoxia in varicose vein formation may lead to the discovery of further therapeutic targets for drug development in this disease.

Future research may need to move away from flawed traditional study designs measuring luminal blood oxygen. Newer molecular techniques including assessing the cellular responses and molecular changes in varicose veins to hypoxia may be more useful [74]. Understanding the molecular changes including the cellular adaptations and responses to hypoxia in varicose veins could help to develop a pharmacologic target.

\section{Acknowledgement}

C.S.L. is funded by the Royal College of Surgeons of England One Year Research Fellowship.

\section{References}

1 Lee AJ, Evans CJ, Allan PL, Ruckley CV, Fowkes FG: Lifestyle factors and the risk of varicose veins: Edinburgh Vein Study. J Clin Epidemiol 2003;56:171-179.

2 International task force. The management of chronic venous disorders of the leg: an evidence-based report of an international task force. Epidemiology. Phlebology 1999; 14(suppl 1):23.

3 Nicolaides AN: Investigation of chronic venous insufficiency: a consensus statement (France, March 5-9, 1997). Circulation 2000; 102:E126-E163.

4 Raffetto JD, Khalil RA: Mechanisms of varicose vein formation: valve dysfunction and wall dilation. Phlebology 2008;23:85-98.

5 Somers P, Knaapen M: The histopathology of varicose vein disease. Angiology 2006;57: 546-555.

6 Lim CS, Davies AH: Pathogenesis of primary varicose veins. Br J Surg 2009;96:1231-1242.

$\checkmark 7$ Lim CS, Shalhoub J, Gohel MS, Shepherd AC, Davies AH: Matrix metalloproteinases in vascular disease - a potential therapeutic target? Curr Vasc Pharmacol 2010;8:75-85.

8 Michiels C, Bouaziz N, Remacle J: Role of the endothelium and blood stasis in the development of varicose veins. Int Angiol 2002;21: $18-25$.

-9 Taccoen A, Lebard C, Borie H, Poullain JC, Zuccarelli F, Gerentes I, Stern S, Guichard M: Measurement of oxygen tension in normal and varicose vein walls (in French). J Mal Vasc 1996;21(suppl C):259-265.

10 Kachlik D, Lametschwandtner A, Rejmontova J, Stingl J, Vanek I: Vasa vasorum of the human great saphenous vein. Surg Radiol Anat 2003;24:377-381.

11 Lefebvre D, Lescalie F: Vascularization of the wall of the superficial veins. Anatomic study of the vasa vasorum (in French). J Mal Vasc 1996;21(suppl C):245-248.

12 Kachlik D, Baca V, Stingl J, Sosna B, Lametschwandtner A, Minnich B, Setina M: Architectonic arrangement of the vasa vasorum of the human great saphenous vein. J Vasc Res 2007;44:157-166.
13 Heistad DD, Armstrong ML, Amundsen S: Blood flow through vasa vasorum in arteries and veins: Effects of luminal $\mathrm{PO}_{2}$. Am J Physiol 1986;250:H434-H442.

14 Bigel P, Taccoen A: Morphology and vascularization of the varicose internal saphenous vein. Comparison with the normal structure (in French). J Mal Vasc 1996;21(supplC):249252.

15 Kachlik D, Stingl J, Sosna B, Straka Z, Lametschwandtner A, Minnich B, Fara P: Morphological features of vasa vasorum in pathologically changed human great saphenous vein and its tributaries. Vasa 2008;37: 127-136.

16 Michiels C, Arnould T, Remacle J: Endothelial cell responses to hypoxia: initiation of a cascade of cellular interactions. Biochim Biophys Acta 2000;1497:1-10.

17 Nicolaides AN: From symptoms to leg edema: Efficacy of Daflon $500 \mathrm{mg}$. Angiology 2003;54(suppl 1):S33-S44.

18 Colm Malone P, Agutter PS: To what extent might deep venous thrombosis and chronic venous insufficiency share a common etiology? Int Angiol 2009;28:254-268.

19 McEwan AJ, McArdle CS: Effect of hydroxyethylrutosides on blood oxygen levels and venous insufficiency symptoms in varicose veins. Br Med J 1971;2:138-141.

20 deTakats G, Quint H, Tillotson BI, Crittenden PJ: The impairment of circulation in the varicose extremity. Arch Surg 1929;18:671.

21 Reikerås O, Sorlie D: The significance of arteriovenous shunting for the development of varicose veins. Acta Chir Scand 1983;149: 479-481.

22 Scott HJ, Cheatle TR, McMullin GM, Coleridge Smith PD, Scurr JH: Reappraisal of the oxygenation of blood in varicose veins. Br J Surg 1990;77:934-936.

23 Holling HE, Beecher HK, Linton RR: Study of the tendency to edema formation associated with incompetence of the valves of the communicating veins of the leg. Oxygen tension of the blood contained in varicose veins. J Clin Invest 1938;17:555-561.
24 Murphy MA, Hands L: Is arteriovenous shunting involved in the development of varicosities? A study of the intraluminal pressure and oxygen content in varicose veins. Phlebology 2008;23:137-141.

25 Schraibman IG: Blood oxygen saturation and dye-dilution studies in the investigation of the aetiology of varicose veins. Aust NZ J Surg 1966;36:136-144.

26 Wali MA: Oxygenation of blood in varicose veins. Afr J Med Med Sci 2002;31:219-222.

27 Blalock A: Oxygen content of blood in patients with varicose veins. Arch Surg 1929; 19:298-305.

28 Baron HC, Cassaro S: The role of arteriovenous shunts in the pathogenesis of varicose veins. J Vasc Surg 1986;4:124-128.

29 Blumoff RL, Johnson G Jr: Saphenous vein $\mathrm{PpO}_{2}$ in patients with varicose veins. J Surg Res 1977;23:35-36.

30 Jacob MP, Cazaubon M, Scemama A, Prie D, Blanchet F, Guillin MC, Michel JB: Plasma matrix metalloproteinase- 9 as a marker of blood stasis in varicose veins. Circulation 2002;106:535-538.

- 31 Takase S, Lerond L, Bergan JJ, SchmidSchonbein GW: The inflammatory reaction during venous hypertension in the rat. Microcirculation 2000;7:41-52.

32 Thomas PR, Nash GB, Dormandy JA: White cell accumulation in dependent legs of patients with venous hypertension: a possible mechanism for trophic changes in the skin. Br Med J (Clin Res Ed) 1988;296:1693-1695.

33 Smith PD: Neutrophil activation and mediators of inflammation in chronic venous insufficiency. J Vasc Res 1999;36(suppl 1):2436.

34 Lengyel I, Acsady G: Histomorphological and pathobiochemical changes of varicose veins. A possible explanation of the development of varicosis. Acta Morphol Hung 1990; 38:259-267.

35 Niebes P: Vessel wall modification in venous pathology. Application to the study of phlebotonic drugs. Int Angiol 1996;15:88-92. 
-36 Glowinski J, Glowinski S: Generation of reactive oxygen metabolites by the varicose vein wall. Eur J Vasc Endovasc Surg 2002;23: 550-555.

-37 Flore R, Santoliquido A, Antonio DL, Pola E, Flex A, Pola R, Muzi MG, Farinon A, Rulli F, Gaetani E, Tondi P, Gerardino L, Gasbarrini A: Long saphenous vein stripping reduces local level of reactive oxygen metabolites in patients with varicose disease of the lower limbs. World J Surg 2003;27:473-475.

-38 Whiston RJ, Hallett MB, Davies EV, Harding KG, Lane IF: Inappropriate neutrophil activation in venous disease. Br J Surg 1994;81: 695-698.

-39 Stvrtinova V, Ferencikova J: Lysosomal enzymes and superoxide production in polymorphonuclear leucocytes of patients with primary varicose veins. Cor Vasa 1992;34: 255-264.

-40 Ciuffetti G, Mannarino E, Paltriccia R, Malagigi V, Sergi F, Paulisch P, Pasqualini L, Lupattelli G: Leucocyte activity in chronic venous insufficiency. Int Angiol 1994;13: 312-316.

41 Bougelet C, Roland IH, Ninane N, Arnould T, Remacle J, Michiels C: Effect of aescine on hypoxia-induced neutrophil adherence to umbilical vein endothelium. Eur J Pharmacol 1998;345:89-95.

$\checkmark 42$ Michiels C, Arnould T, Remacle J: Hypoxiainduced activation of endothelial cells as a possible cause of venous diseases: hypothesis. Angiology 1993;44:639-646.

$\checkmark 43$ Arnould T, Michiels C, Alexandre I, Remacle $\mathrm{J}$ : Effect of hypoxia upon intracellular calcium concentration of human endothelial cells. J Cell Physiol 1992;152:215-221.

44 Janssens D, Michiels C, Delaive E, Eliaers F, Drieu K, Remacle J: Protection of hypoxiainduced ATP decrease in endothelial cells by Ginkgo biloba extract and bilobalide. Biochem Pharmacol 1995;50:991-999.

45 Michiels C, Arnould T, Knott I, Dieu M, Remacle J: Stimulation of prostaglandin synthesis by human endothelial cells exposed to hypoxia. Am J Physiol 1993;264:C866-C874.

-46 Michiels C, De Leener F, Arnould T, Dieu M, Remacle J: Hypoxia stimulates human endothelial cells to release smooth muscle cell mitogens: role of prostaglandins and bFGF. Exp Cell Res 1994;213:43-54.

47 Michiels C, Bouaziz N, Remacle J: Role of the endothelium and blood stasis in the appearance of varicose veins. Int Angiol 2002;21: $1-8$.

-48 Calvani M, Rapisarda A, Uranchimeg B, Shoemaker RH, Melillo G: Hypoxic induction of an HIF- $1 \alpha$-dependent bFGF autocrine loop drives angiogenesis in human endothelial cells. Blood 2006;107:2705-2712.
49 Zhu XY, Daghini E, Chade AR, Lavi R, Napoli C, Lerman A, Lerman LO: Disparate effects of simvastatin on angiogenesis during hypoxia and inflammation. Life Sci 2008;83: 801-809.

50 Jiang J, Xia XB, Xu HZ, Xiong Y, Song WT, Xiong SQ, Li Y: Inhibition of retinal neovascularization by gene transfer of small interfering RNA targeting HIF- $1 \alpha$ and VEGF. Cell Physiol 2009;218:66-74.

-51 Haider DG, Bucek RA, Giurgea AG, Maurer G, Glogar H, Minar E, Wolzt M, Mehrabi MR, Baghestanian M: $\mathrm{PGE}_{1}$ analog alprostadil induces VEGF and ENOS expression in endothelial cells. Am J Physiol Heart Circ Physiol 2005;289:H2066-H2072.

52 Coulet F, Nadaud S, Agrapart M, Soubrier F: Identification of hypoxia-response element in the human endothelial nitric-oxide synthase gene promoter. J Biol Chem 2003;278: 46230-46240.

53 Semenza GL: Regulation of oxygen homeostasis by hypoxia-inducible factor 1 . Physiology (Bethesda) 2009;24:97-106.

54 Cook-Johnson RJ, Demasi M, Cleland LG, Gamble JR, Saint DA, James MJ: Endothelial cell COX-2 expression and activity in hypoxia. Biochim Biophys Acta 2006;1761:14431449

55 Matagne D, Gilles R: Effect of $O-(\beta$ hydroxyethyl)-rutoside on the glucose metabolism of cultured human varicose saphenous veins. Arch Int Physiol Biochim 1977 85:133-138.

56 Aunapuu M, Arend A: Histopathological changes and expression of adhesion molecules and laminin in varicose veins. Vasa 2005;34:170-175.

57 Arnould T, Janssens D, Michiels C, Remacle J: Effect of aescine on hypoxia-induced activation of human endothelial cells. Eur J Pharmacol 1996;315:227-233.

58 Arnould T, Michiels C, Janssens D, Delaive E, Remacle J: Hypoxia induces pmn adherence to umbilical vein endothelium. Cardiovasc Res 1995;30:1009-1016.

59 Arnould T, Michiels C, Remacle J: Increased PMN adherence on endothelial cells after hypoxia: Involvement of PAF, CD18/CD11b, and ICAM-1. Am J Physiol 1993;264:C1102C1110.

60 Arnould T, Michiels C, Remacle J: Hypoxic human umbilical vein endothelial cells induce activation of adherent polymorphonuclear leukocytes. Blood 1994;83:3705-3716.

61 Michiels C, Arnould T, Thibaut-Vercruyssen R, Bouaziz N, Janssens D, Remacle J: Perfused human saphenous veins for the study of the origin of varicose veins: role of the endothelium and of hypoxia. Int Angiol 1997; 16:134-141.
62 Michiels C, Remacle J, Bouaziz N: Endothelium and venotropic drugs in chronic venous insufficiency: a review. Phlebology 2002;17: 145-150.

63 Martinez MJ, Bonfill X, Moreno RM, Vargas E, Capella D: Phlebotonics for venous insufficiency. Cochrane Database Syst Rev 2005;CD003229.

64 Janssens D, Delaive E, Houbion A, Eliaers F, Remacle J, Michiels C: Effect of venotropic drugs on the respiratory activity of isolated mitochondria and in endothelial cells. Br J Pharmacol 2000;130:1513-1524.

65 Guilhou JJ, Dereure O, Marzin L, Ouvry P, Zuccarelli F, Debure C, Van Landuyt H, Gillet-Terver MN, Guillot B, Levesque $\mathrm{H}, \mathrm{Mi}-$ gnot J, Pillion G, Fevrier B, Dubeaux D: Efficacy of Daflon $500 \mathrm{mg}$ in venous leg ulcer healing: a double-blind, randomized, controlled versus placebo trial in 107 patients. Angiology 1997;48:77-85.

66 Struckmann JR: Clinical efficacy of micronized purified flavonoid fraction: an overview. J Vasc Res 1999;36(suppl 1):37-41.

67 Gohel MS, Davies AH: Pharmacological agents in the treatment of venous disease: An update of the available evidence. Curr Vasc Pharmacol 2009; 7:303-308

68 MacKay D: Hemorrhoids and varicose veins: a review of treatment options. Altern Med Rev 2001;6:126-140.

69 Taccoen A, Belcaro G, Lebard C, Zuccarelli F: Pathogenesis and underlying mechanisms of varicose veins: review and future prospects. Sang Thrombose Vaisseaux 1997;9: 354-363.

70 Michiels C, Arnould T, Janssens D, Bajou K, Geron I, Remacle J: Interactions between endothelial cells and smooth muscle cells after their activation by hypoxia. A possible etiology for venous disease. Int Angiol 1996;15: 124-130.

71 Boyce JA, Mellor EA, Perkins B, Lim YC, Luscinskas FW: Human mast cell progenitors use $\alpha 4$-integrin, VCAM-1, and PSGL-1 E-selectin for adhesive interactions with human vascular endothelium under flow conditions. Blood 2002;99:2890-2896.

72 Birukov KG: Cyclic stretch, reactive oxygen species, and vascular remodeling. Antioxid Redox Signal 2009;11:1651-1667.

$\checkmark 73$ Koskinas KC, Chatzizisis YS, Baker AB, Edelman ER, Stone PH, Feldman CL: The role of low endothelial shear stress in the conversion of atherosclerotic lesions from stable to unstable plaque. Curr Opin Cardiol 2009;24:580-590

74 Lim CS, Gohel MS, Davies AH: Is there still a role for basic science research in venous disease? Phlebology 2008;23:147-148. 